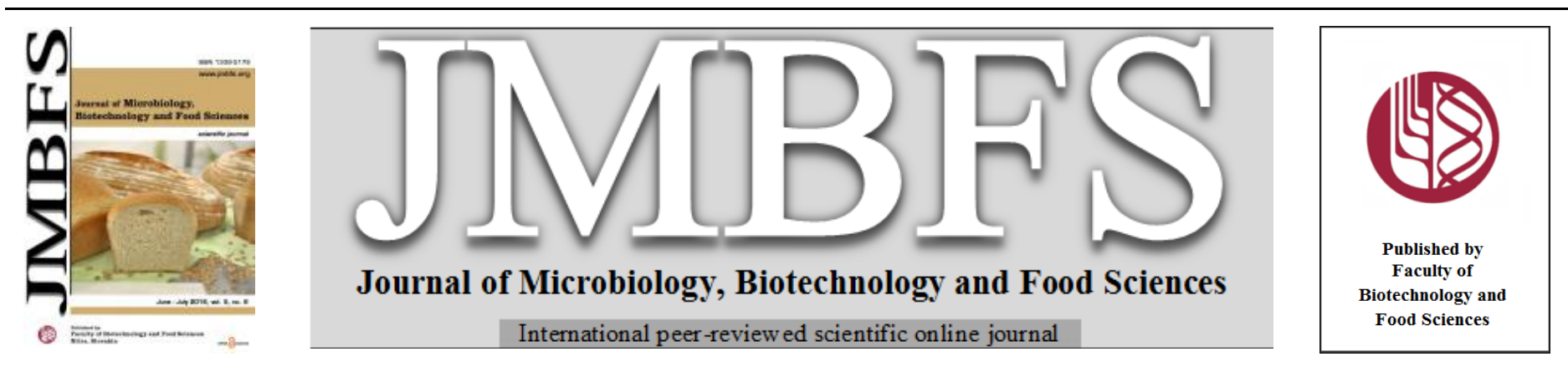

\title{
ECOLOGY OF PANTOEA AGGLOMERANS 2066-7 STRAIN: A BIOLOGICAL CONTROL OF BACTERIA ONION DISEASES
}

\author{
Soumia Sadik $^{* 1,2}$, Hamid Mazouz ${ }^{2}$, Abdellatif Benbouazza ${ }^{1}$, and El Hassan Achbani* ${ }^{1}$ \\ Address(es): PhD student, Miss Soumia Sadik, \\ ${ }^{1}$ Laboratory of Plant Protection URPP- INRA, 50000-Meknes, Morocco, phone number: +212679897059/+212650198107. \\ ${ }^{2}$ Laboratory of Plant Biotechnology and Molecular Biology, Faculty of Sciences, 50000 Meknes, Morocco.
}

*Corresponding author: achbani105@gmail.com, sadik.soumia@hotmail.com

doi: $10.15414 / j m b f s .2016 .5 .6 .612-616$

\section{ARTICLE INFO}

Received 11. 6. 2015

Revised 19. 2. 2016

Accepted 1.3. 2016

Published 1. 6. 2016

Regular article

OPEN OACCESS $_{\text {A }}$

\section{ABSTRACT}

The growth response of the biocontrol agent Pantoea agglomerans 2066-7 to change in water activity $\left(\mathrm{a}_{\mathrm{w}}\right)$, temperature, and $\mathrm{pH}$ was determined in vitro in basic medium. The minimum temperature at which 2066-7 was able to grow was $7^{\circ} \mathrm{C}$, and the growth of 2066-7 did not change at varying $\mathrm{pH}$ levels (4-10.34). The best growth was obtained at a water activity of 0.98 in all media modified with the four solutes (glucose, glycerol, $\mathrm{NaCl}$ and polyethylene glycol). The solute used to reduce water activity had a great influence on bacterial growth, especially at unfavorable conditions (low temperature). This study has defined the range of environmental conditions $\left(\mathrm{a}_{\mathrm{w}}, \mathrm{pH}\right.$, and temperature) over which the bacteria may be developed for biological control of plant diseases.

Keywords: Pantoea agglomerans, ecology, water activity and plant diseases

\section{INTRODUCTION}

The control of diseases in fruits and vegetables is still mainly based on the use of synthetic pesticides, although the demand for produce free from chemical residues and the emergence of pesticides -resistant pathogen strains is constantly increasing.

Biological control using microbial antagonists has attracted much interest as an alternative to chemical products (Droby and Chalutz, 1992; Vinas et al., 1998). However, very few of the biocontrol agents studied have been successfully commercialized.

Following application on fruits and vegetables, biocontrol agents are exposed to a range of variable biotic and abiotic stress factors, such as competition, predation, changes in temperature, osmolarity, low $\mathrm{pH}$, availability of nutrients and water. Therefore, biocontrol in the field has often been limited by fluctuating environment and the narrow range of conditions over which successful establishment and effective pest and/or disease control is possible (Hallsworth and Magan, 1994a,b).

Dehydration of the product and maintenance in a dry environment is one of the best way to formulate microbial agents, so that they can be handled using the normal distribution and storage channels (Rhodes, 1993).

Unfortunately, not all microorganisms are amenable to drying and many tend to lose viability during both the drying process and storage. Biological systems are currently preserved by reducing their water content and thereby the water activity $\left(a_{w}\right)$ of the medium. Thus, water activity is a measure of the availability of water for biological functions and relates to water present in a food in "free" form. In food system, total water of moisture is present in "free" and "bound" forms. Bound water is necessary to hydrate the hydrophilic molecules and to dissolve the solutes and not available for biological functions; as well, it does not contribute to water activity. The free water in a food is necessary for microbial growth. It is necessary for the transport of nutrients and the removal of waste materials, to carry out enzymatic reactions, to synthesize cellular materials, and to take part in other biochemical reactions. Each microbial species (or group) has an optimum, maximum, minimum water activity level for growth. When the water activity is reduced below the minimal level for growth of a microorganism, the cells remain viable for a while. Nevertheless, if the water activity is reduced drastically, microbial cells will lose viability, generally rapidly at first, and then more slowly (Magan and Lacey, 1988; Plaza et al., 2003; mathlouthi, 2001).

Temperatures and $\mathrm{pH}$ of environment are also limited factors to the development of microorganisms. However, to assure a good application of biological control agent in the field and during storage a study of the optimal water activity, temperatures and $\mathrm{pH}$ of development of this agent is very important (Cañamás et al., 2009).

In this work and at the first time in Morocco we studied the ecology of a biological control agent of onion bacteria disease. The experiments were conducted in the laboratory of Plant Protection URPP- INRA-Meknes in collaboration with the Laboratory of Plant Biotechnology and Molecular Biology, Faculty of Sciences-Meknes. The main objective of this work is to study the improvement of $\mathrm{a}_{\mathrm{w}}$, temperature and $\mathrm{pH}$ tolerance observed in Pantoea agglomerans 2066-7.

\section{MATERIALS AND METHODS}

\section{Effect of temperature on growth of $P$. agglomerans}

To test the ability of $P$. agglomerans 2066-7 to grow at different temperatures onto YPGA medium (5 g.L.-1 yeast, 5 g.L $\mathrm{L}^{-1}$ peptone and $10 \mathrm{~g} . \mathrm{L}^{-1}$ glucose, 18 g.L $\mathrm{L}^{-1}$ agar), the bacterium was incubated during 24 to $48 \mathrm{~h}$ under $7^{\circ} \mathrm{C}, 25^{\circ} \mathrm{C}, 30^{\circ} \mathrm{C}$, $36^{\circ} \mathrm{C}, 38^{\circ} \mathrm{C}$ and $40^{\circ} \mathrm{C}$.

\section{Effect of pH on growth of $P$. agglomerans}

In order to perform the survival study, $9 \mathrm{~mL}$ of non-acidified (control $\mathrm{pH} 6.9 \pm$ 0.1 ) and liquid media at pHs $2,3,3.5,4,4.5,5,6,7,8,9,10$ or 13 ,were inoculated with Pantoea agglomerans 2066-7. From the pre-culture, the liquid medium was inoculated by $20 \mu \mathrm{L}$ of $10^{7} \mathrm{UFC} \cdot \mathrm{mL}^{-1}$ of $P$. agglomerans suspension. The medium employed was "YPG", consisted of 5 g.L ${ }^{-1}$ yeast, 5 g.L - $^{-1}$ peptone and 10 g. $\mathrm{L}^{-1}$ glucose, for the culture of $P$. agglomerans. All $\mathrm{pH}$ determinations were made with the Beckman $\mathrm{pH}$ meter, and the $\mathrm{pH}$ was adjusted with normal $\mathrm{HCI}$ or normal $\mathrm{NaOH}$. The growth was tested by measure of optical density by spectrophomometre $(600 \mathrm{~nm})$.

Non- acidified basal liquid medium was used as a control.

\section{Population dynamics of $P$. agglomerans}

Population dynamics of 2066-7 P. agglomerans bacterium were determined on the surfaces of onion bulbs, with or without wounds. Two sets of bulbs were rinsed in fresh water after harvest. One of these sets was wounded (1 mm long and $2 \mathrm{~mm}$ deep). All bulbs were dipped in a 2066-7 suspension $10^{8} \mathrm{CFU} \mathrm{mL}^{-1}$ for $30 \mathrm{~s}$. Once dried, bulbs were placed on tray packs in plastic boxes and incubated at moist chamber at $7{ }^{\circ} \mathrm{C}$ and $25^{\circ} \mathrm{C}$. Populations of 2066-7 were monitored at 0 (just prior to storage), 24, 48, 288 and $312 \mathrm{~h}$ on bulbs stored at $25^{\circ} \mathrm{C}$, and $0,1,2$, 
18, 20, and 21 days on cold stored bulbs. Four bulbs constituted a single replicate and each treatment was replicated four times. The experiment was carried out twice

The pieces of peel surface of $1 \mathrm{~g}$ were removed (including the wounded areas in the case of wounded bulbs) with a knife. Pieces of peel were shaken in $9 \mathrm{ml}$ sterile water on agitator for $30 \mathrm{mins}$ with $125 \mathrm{t} / \mathrm{min}$. Serial dilutions of the washings were made and plated on YPGA Medium (yeast extract, $5 \mathrm{~g} . \mathrm{L}^{-1}$; peptone, $5 \mathrm{~g}$. $\mathrm{L}^{-1}$; glucose, $10 \mathrm{~g} . \mathrm{L}^{-1}$ and agar, $\left.15 \mathrm{~g} . \mathrm{L}^{-1}\right)$. Colonies were counted after incubation at $25^{\circ} \mathrm{C}$ in the dark for $48 \mathrm{~h}$. Population sizes were expressed as $\mathrm{CFU} \mathrm{ml}{ }^{-1}$ of bulb surface.

\section{Effect of water activity on growth of $P$. agglomerans}

\section{Basic medium}

The basic medium used in this research consisted of sucrose $\left(10 \mathrm{~g} . \mathrm{L}^{-1}\right)$ plus yeast extract $\left(5 \mathrm{~g} . \mathrm{L}^{-1}\right)$ with a $\mathrm{pH}$ of 6-7 and $\mathrm{a}_{\mathrm{w}}$ of 0.995 (Costa et al., 2001). This medium demonstrated good and cost-effective production while maintaining biological control efficacy.

\section{Osmotic stress characterization with different solutes}

To obtain information about the $\mathrm{a}_{\mathrm{w}}$ solute profile of $P$. agglomerans bacterium, was grown in basic liquid medium and a known amount of CFU were inoculated in Petri dishes that contained the basal agar medium modified with the ionic solute; $\mathrm{NaCl}$ and with the nonionic solutes; glycerol, glucose and polyethylene glycol (PEG 600), to 0.98, 0.97, 0.96 and $0.95 \mathrm{a}_{\mathrm{w}}$ (Teixido et al., 2006). The solid agar media were inoculated by spread plating a $20 \mu \mathrm{L}$ aliquot of a $10^{5} \mathrm{CFU}$ $\mathrm{mL}^{-1}$ bacterial suspension of $P$. agglomerans incubated at $7{ }^{\circ} \mathrm{C}, 25^{\circ} \mathrm{C}$ and $30^{\circ} \mathrm{C}$ and then visually examined them every $24 \mathrm{~h}$ to determine the presence or absence of growth of colonies. This was performed for each $\mathrm{a}_{\mathrm{w}}$ and solute condition. All treatments were carried out with four replicates, and the experiment was repeated twice.

Media from the same $a_{w}$ were always sealed in plastic polyethylene bags to maintain the equilibrium relative humidity conditions and prevent water loss. Percentage of cultivability was calculated comparing CFU on treatments in relation with the control (basal agar medium).

\section{Statistical analysis}

Growth rates were subjected to the variance analysis (SAS Institute, INRA). Statistical significance was judged at the $\mathrm{P}<0.05$ level. When analysis revealed statistically significant differences, Duncan's multiple range test for separation of means was performed.

Response surface methodology (RSM) with a generalized linear model design was applied with the SPSS 20 . Temperature $\left(7,25\right.$ and $\left.30^{\circ} \mathrm{C}\right)$ and $\mathrm{a}_{\mathrm{w}}(0.98,0.97$, 0.96 and 0.95 ) were investigated.

\section{RESULTS}

\section{Effect of temperature on growth of $P$. agglomerans}

Table 1, show the ability of $P$. agglomerans strain to growth at a temperature from $7^{\circ} \mathrm{C}$ to $38^{\circ} \mathrm{C}$

Table 1 Temperature influence on growth of $P$. agglomerans 2066-7 strain

\begin{tabular}{lllllll}
\hline Temperature & $\mathbf{7}^{\circ} \mathbf{C}$ & $\mathbf{2 5}^{\circ} \mathbf{C}$ & $\mathbf{3 0}^{\circ} \mathbf{C}$ & $\mathbf{3 6}^{\circ} \mathbf{C}$ & $\mathbf{3 8}^{\circ} \mathbf{C}$ & $\mathbf{4 0}^{\circ} \mathbf{C}$ \\
\hline Growth rate & $(+)$ & $(+)$ & $(+)$ & $(+)$ & $(+)$ & $(-)$
\end{tabular}

Legend: (+) Growth, (-) Absence of growth

\section{Effect of $\mathrm{pH}$ on growth of $P$. agglomerans}

Figure 1, show the adaptation of P.agglomerans at large range of $\mathrm{pH}$ conditions. The initial of colony growth was observed after $24 \mathrm{~h}$ of incubation on the basic and acidified medium (from 4 to 10.34). The growth was absent in a $\mathrm{pH}$ values less than 4 and high than 10.34 .

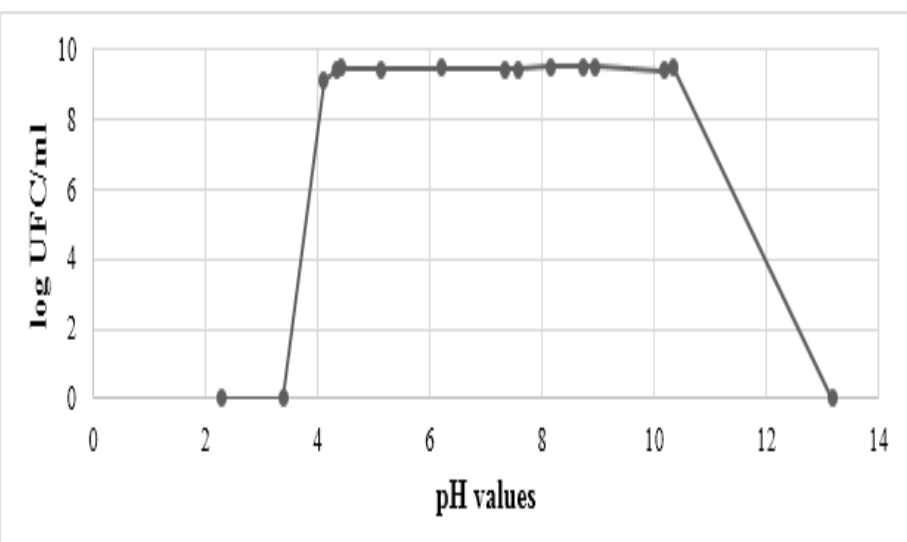

Figure 1 Effect of $\mathrm{pH}$ on P. agglomerans 2066-7 growth

Population dynamics of $P$. agglomerans bacterium

Population of $P$. agglomerans on bulb surfaces showed the same pattern under the two tested temperature conditions (Fig.2). During the first 24h, the population degreased to return to the initial concentration after 12 and 20 days of incubation under $25^{\circ} \mathrm{C}$ and cold temperature respectively.
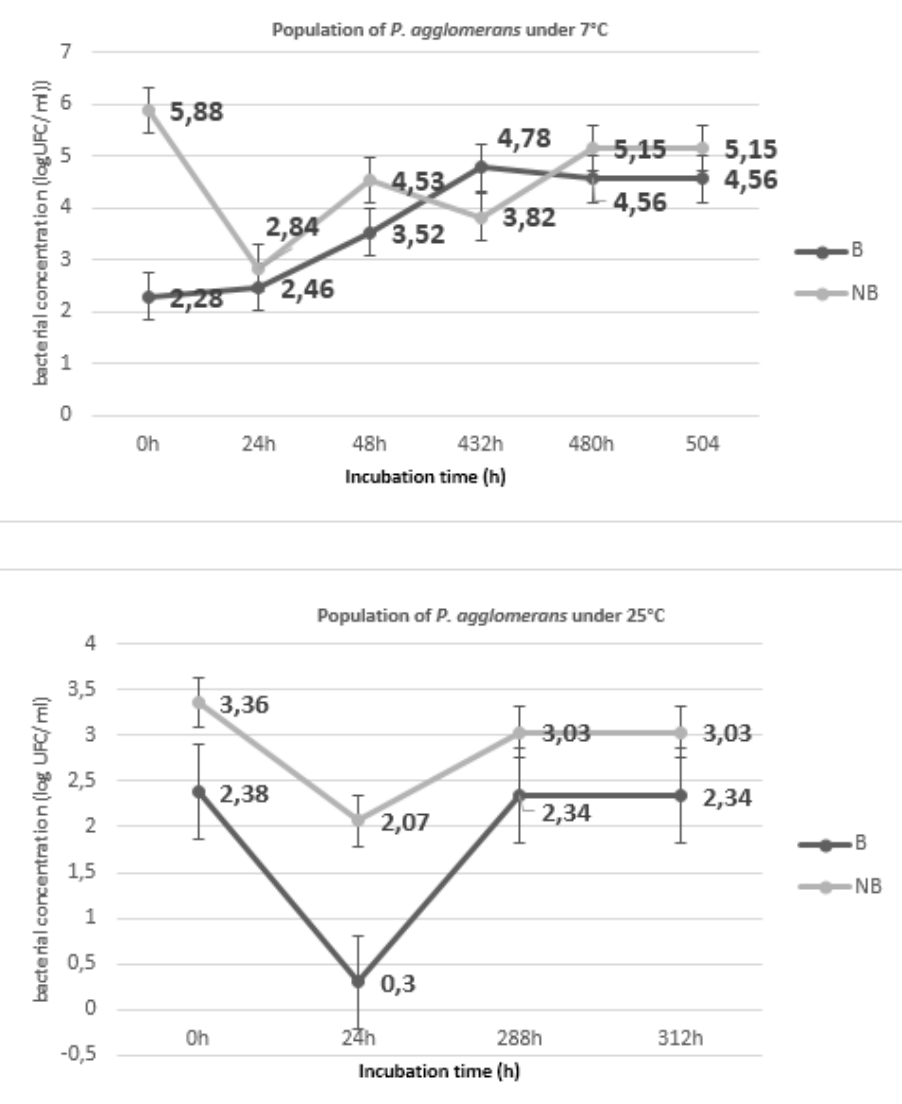

Figure 2 Population dynamics of $P$. agglomerans 2066-7 on surfaces of unwounded (NB). and wounded (B). Onion bulbs incubated at $7^{\circ} \mathrm{C}$ for 21 days and at $25^{\circ} \mathrm{C}$ for 13 days. Points represent the means of four replicates and the vertical bars are standard errors.

\section{Osmotic stress characterization with different solutes}

The cultivability of $P$. agglomerans at suboptimum $\mathrm{a}_{\mathrm{w}}$ media modified with different solutes is shown in figure 3 . The growth of the bacterium was very limited in the presence of glucose under $7^{\circ} \mathrm{C}$ and $30^{\circ} \mathrm{C}$ and in the presence of glycerol under $7^{\circ} \mathrm{C}$. However, it was completely inhibited at values of $\mathrm{a}_{\mathrm{w}} \leq 0.97$ and at 0.95 under $25^{\circ} \mathrm{C}$ on the presence of glycerol and glucose respectively. Generally, under of greater water stress and low temperature there was increased in lag times prior to growth initiation. All solutes exhibited $100 \%$ cultivability or near than at $\geq 0.96$ under $25^{\circ} \mathrm{C}$. These results reflect a good adaptation of P.agglomerans on modified medium under $25^{\circ} \mathrm{C}$. 
$25^{\circ} \mathrm{C}$

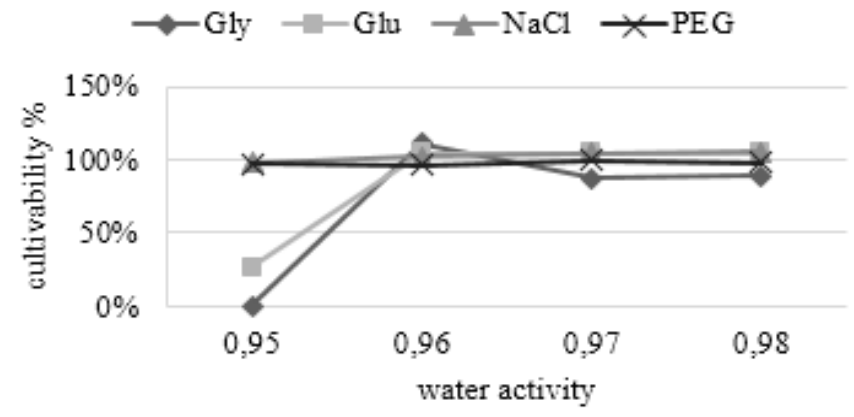

$30^{\circ} \mathrm{C}$

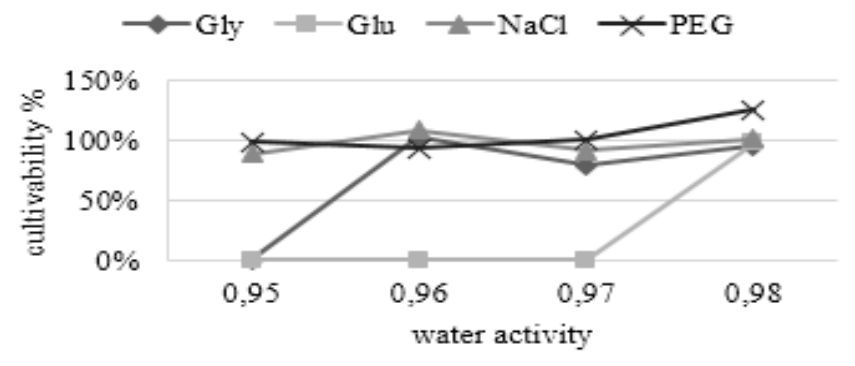

$7^{\circ} \mathrm{C}$

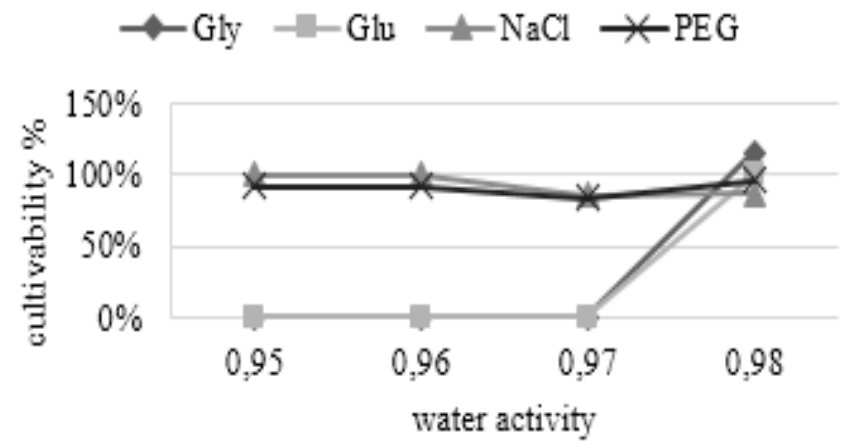

Figure 3 Percentage of cultivability ( $\mathrm{CFU}$ on treatments in relation with $\mathrm{CFU}$ on control basic agar medium) of $P$. agglomerans on low water activity $\left(\mathrm{a}_{\mathrm{w}}\right)$ modified media using different solutes: glycerol (Gly), polyethylene glycol (PEG), glucose (Glu) and $\mathrm{NaCl}$. Tested $\mathrm{a}_{\mathrm{w}}$ were $0.98,0.97,0.96$ and 0.95 . Values are mean of two experiments of four replicates each.

Figure 4 , show the growth rate $(\mu((\operatorname{LogUFC} * 10 \exp 2 / \mathrm{mL}) / \mathrm{j}))$ of $P$. agglomerans at $7^{\circ} \mathrm{C}$ on the basic medium supplemented with various solutes us to adjust the water activity. In general, the growth rate degreased as the water activity of the medium degreased. The growth rate was highest at water activity of 0.98 whatever the solute. In the presence of polyethylene glycol or $\mathrm{NaCl}, P$. agglomerans was able to grow at all values of $\mathrm{a}_{\mathrm{w}}$. However, the growth stopped at $\mathrm{a}_{\mathrm{w}}$ of 0.95 in the presence of glucose or glycerol.

At $25^{\circ} \mathrm{C}$, initial of colony growth advanced one day as compared to initiation at $7^{\circ} \mathrm{C}$, moreover, the growth rate was higher at $25^{\circ} \mathrm{C}$ than at $7{ }^{\circ} \mathrm{C}$. At $\mathrm{a}_{\mathrm{w}}$ of 0.96 and 0.95 the growth rate was highest on basic medium supplemented with glycerol or glucose and $\mathrm{NaCl}$ or polyethylene glycol respectively. Growth was stopped at $0.95 \mathrm{a}_{\mathrm{w}}$ in the presence of glucose or glycerol. On basic medium supplemented with polyethylene glycol or $\mathrm{NaCl}, P$. agglomerans was able to grow at all $\mathrm{a}_{\mathrm{w}}$ values tested at $30^{\circ} \mathrm{C}$, the growth stopped at 0.97 and 0.95 on modified medium by glucose and $\mathrm{NaCl}$ respectively. Growth rates were much lower as at $30^{\circ} \mathrm{C}$ than $25^{\circ} \mathrm{C}$ and at $7{ }^{\circ} \mathrm{C}$ than $30^{\circ} \mathrm{C}$.

Statistical analysis of data, based on variance analysis with three criteria, provided evidence of significant effect $(\mathrm{P}<0.05)$ of solutes and incubation temperature and interactions thereof on the growth rate of $P$. agglomerans. Duncan's multiple range analysis confirmed a significantly higher growth rate at 0.98 that any other conditions tested, whatever the solute used to adjust the $\mathrm{a}_{\mathrm{w}}$ of the medium (Fig.5-A). Apropos of incubation temperature, the higher growth rate was noted under $25^{\circ} \mathrm{C}$ with a value of $\left.1.7718(\operatorname{LogUFC} * 10 \exp 2 / \mathrm{mL}) / \mathrm{j}\right)$, under $7^{\circ} \mathrm{C}$ the value was 0.94 (LogUFC*10exp2/mL)/j) (Fig.5-C).

Finally, the test revealed two distinct groups for the influence of solutes; the growth rate was slightly high on medium modified with polyethylene glycol (1.69) or glycerol (1.52) that unmodified medium (1.516), and reduced when $\mathrm{NaCl}(1.50)$ added and reduced more strongly in the presence of glucose $(0.59)$ (Fig.5-B).

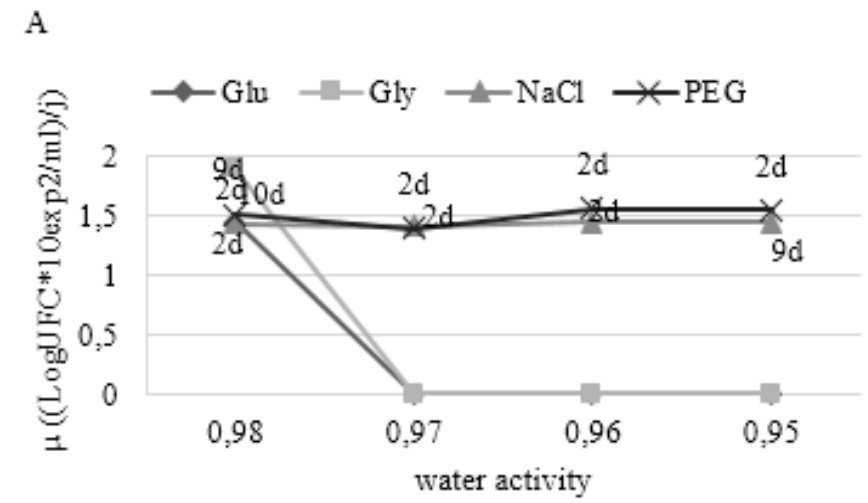

B

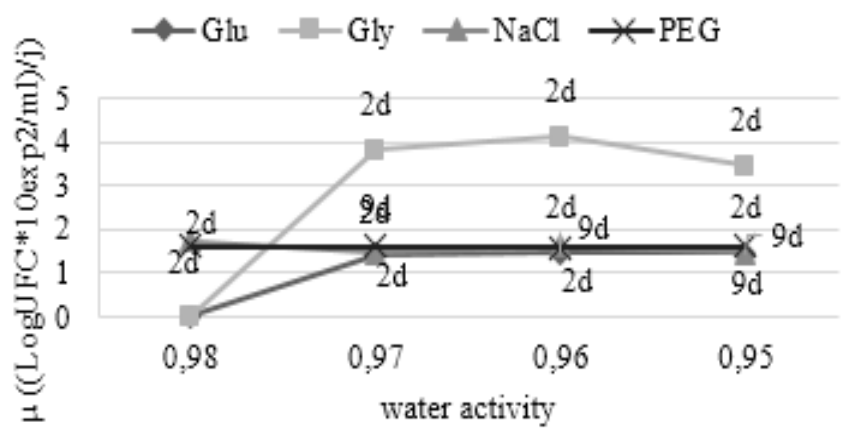

$\mathrm{C}$

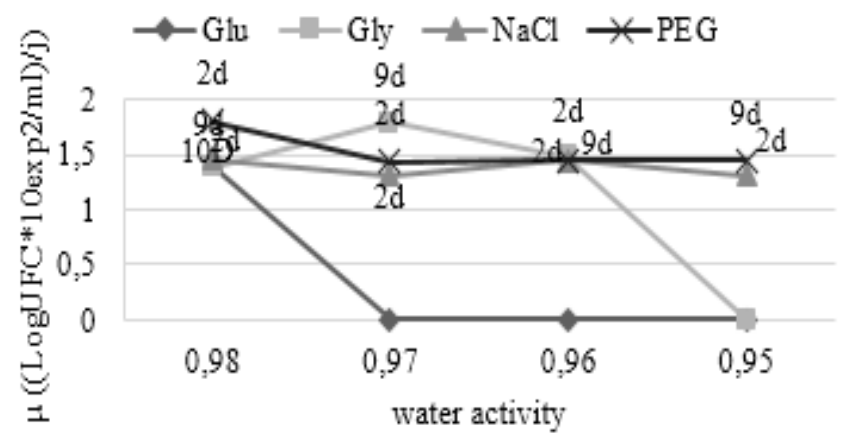

(

Figure 4 Effect of water activity on growth rate $(\mu)$ of P. agglomerans in modified medium with, glycerol (Gly), polyethylene glycol (PEG), glucose (Glu) and $\mathrm{NaCl}$ at $7{ }^{\circ} \mathrm{C}(\mathrm{A}), 25^{\circ} \mathrm{C}(\mathrm{B})$ and $30^{\circ} \mathrm{C}(\mathrm{C})$. The number of days for initiation of growth is shown. 


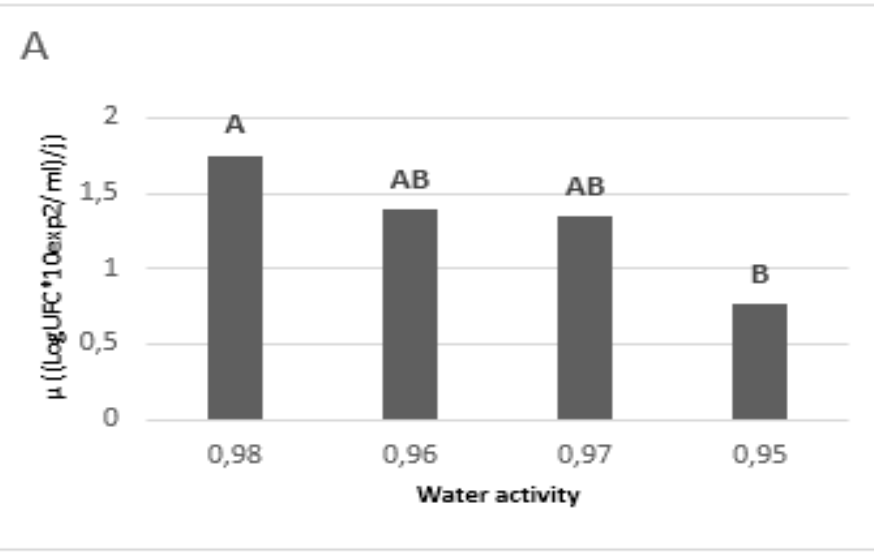

B

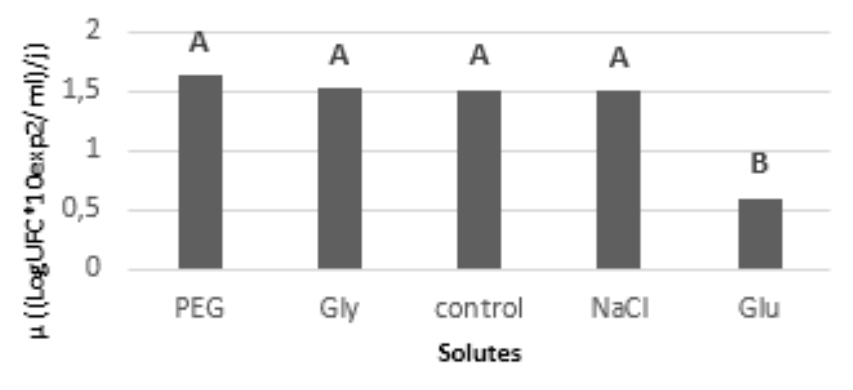

C

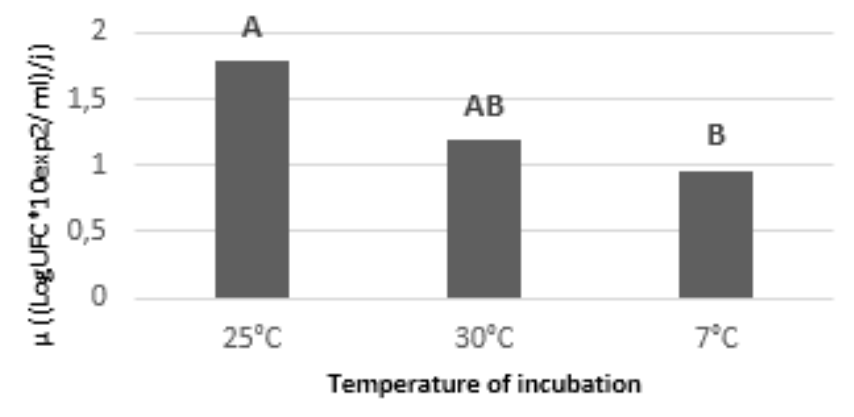

Figure 5 Comparison of $P$. agglomerans growth rate $(\mu)$ averages per treatment [water activity (A), solutes (B) and temperature of incubation (C)] performed by the Duncan's range multiple test. The treatments having same letters are not significantly different $(\mathrm{P}<0.05)$.

\section{Modelling}

The average growth rates obtained with the model under the various conditions are reported in the table 2 . No difference was observed between the observed values and those predicted by the all solutes model. To determine the conditions for growth of $P$. agglomerans, responses showing the predicted effect of $\mathrm{a}_{\mathrm{w}}$ and temperature were down from the generalized linear model. For the four models (Fig.6), the response surface showed a growth rate sensitive to the incubations temperature and water activity.

Growth was predicted to be higher at an $a_{w}$ of 0.98 , whatever the temperature tested, the highest growth rate was observed, and the optimum of growth rate was noted at 0.96 under $25^{\circ} \mathrm{C}$.

Table 2 Experimental and predicted values of growth rate of $P$. agglomerans obtained by applying generalized linear model for temperature and $\mathrm{a}_{\mathrm{w}}$ with glycerol, polyethylene glycol and $\mathrm{NaCl}$ models

\begin{tabular}{llcccccc}
\hline \multicolumn{2}{l}{ Environment factor } & \multicolumn{7}{c}{ Extension growth rate } \\
\hline \multirow{2}{*}{ Temperature } & \multirow{2}{*}{$\mathrm{a}_{\mathrm{w}}$} & \multicolumn{2}{c}{ Glycerol } & \multicolumn{1}{c}{ polyethylene glycol } & \multicolumn{2}{c}{$\mathrm{NaCl}$} \\
\cline { 3 - 9 } & & Observed & Predicted & Observed & Predicted & Observed & Predicted \\
\hline $\mathbf{7}^{\circ} \mathbf{C}$ & 0.95 & 0 & 0 & 1.6 & 1.6 & 1.44 & 1.44 \\
\hline $\mathbf{2 5}{ }^{\circ} \mathbf{C}$ & 0.95 & 0 & 0 & 1.644 & 1.644 & 1.72 & 1.72 \\
\hline $\mathbf{3 0}^{\circ} \mathbf{C}$ & 0.95 & 0 & 0 & 1.45 & 1.45 & 1.37 & 1.37 \\
\hline $\mathbf{7}^{\circ} \mathbf{C}$ & 0.96 & 0 & 0 & 1.66 & 1.66 & 1.44 & 1.44 \\
\hline $\mathbf{2 5}^{\circ} \mathbf{C}$ & 0.96 & 4.2 & 4.2 & 1.62 & 1.62 & 1.62 & 1.62 \\
\hline $\mathbf{3 0}^{\circ} \mathbf{C}$ & 0.96 & 1.5 & 1.5 & 1.53 & 1.53 & 1.71 & 1.71 \\
\hline $\mathbf{7}^{\circ} \mathbf{C}$ & 0.97 & 0 & 0 & 1.42 & 1.42 & 1.41 & 1.41 \\
\hline $\mathbf{2 5}^{\circ} \mathbf{C}$ & 0.97 & 3.85 & 3.85 & 1.62 & 1.62 & 1.457 & 1.457 \\
\hline $\mathbf{3 0}^{\circ} \mathbf{C}$ & 0.97 & 1.96 & 1.96 & 1.55 & 1.55 & 1.44 & 1.44 \\
\hline $7^{\circ} \mathbf{C}$ & 0.98 & 1.89 & 1.89 & 1.65 & 1.65 & 1.43 & 1.43 \\
\hline $\mathbf{2 5}^{\circ} \mathbf{C}$ & 0.98 & 3.45 & 3.45 & 1.62 & 1.62 & 1.45 & 1.45 \\
\hline $\mathbf{3 0}^{\circ} \mathbf{C}$ & 0.98 & 1.44 & 1.44 & 2.23 & 2.23 & 1.54 & 1.54 \\
\hline
\end{tabular}
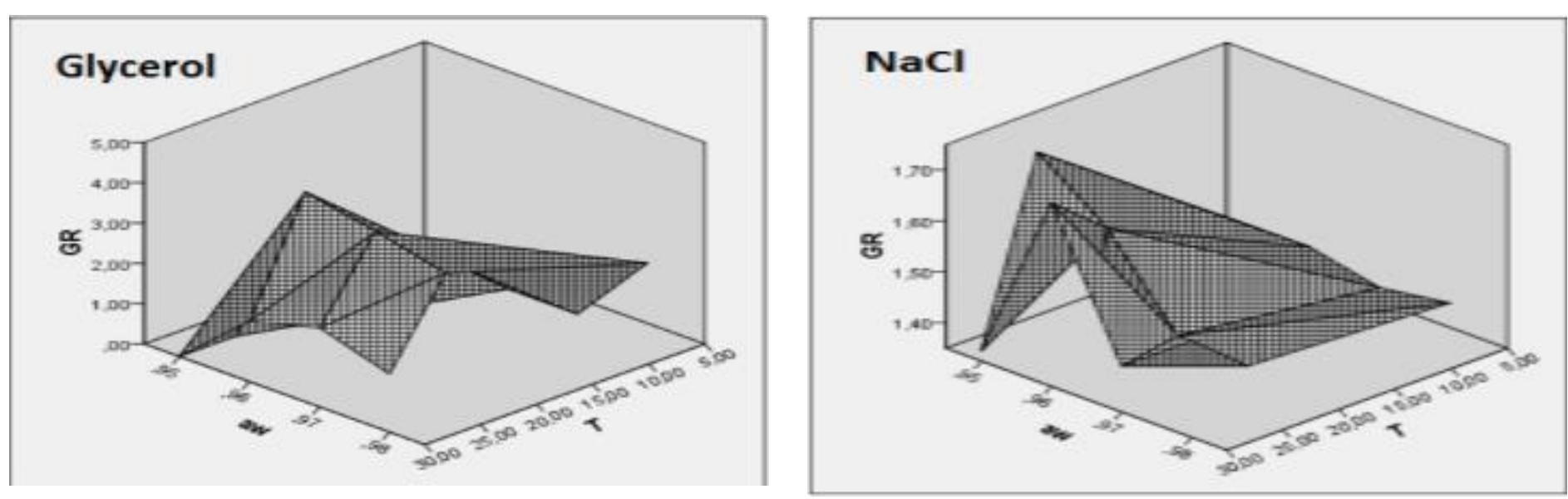


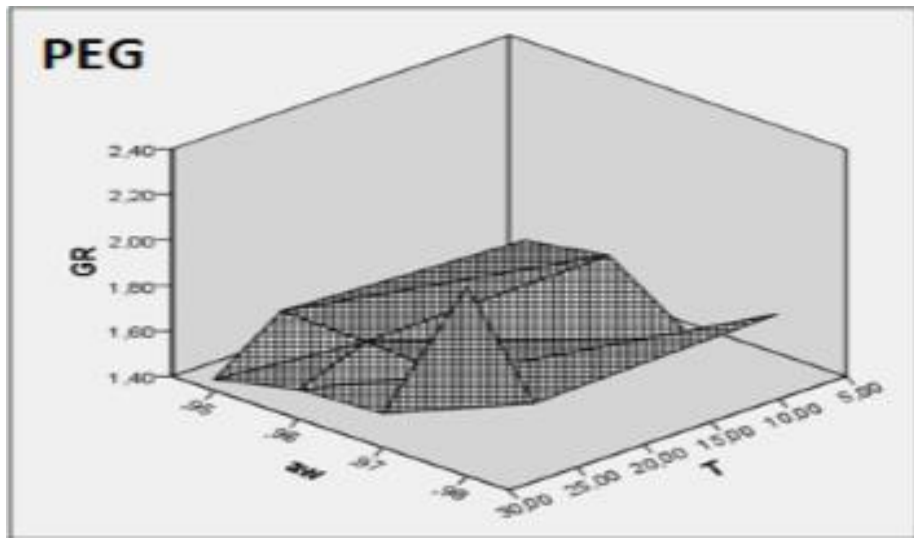

Figure 6 Response surface representing the predicted effect of water activity (aw) and temperature (T) by the three models glycerol, $\mathrm{NaCl}$ and Polyethylene glycol (PEG) on growth rate of P. agglomerans (GR).

\section{DISCUSSION}

Biological control under laboratory or controlled conditions has been demonstrated to be very effective in controlling bacteria disease in large number of studies. However, few biological control products have been commercialized and effectively used under practical conditions. The main reason for this relative lack of success is probably the fact that biological control agents are living organisms and thus limited by fluctuating environmental conditions both during application (with field conditions being the most restrictive) and the formulation process and shelf life. In this work, we tried to improve tolerance of $P$. agglomerans to low $\mathrm{a}_{\mathrm{w}}$ and survival during the drying process with osmotic stress, survival on onion bulbs under $25^{\circ} \mathrm{C}$ and cold temperature $\left(7^{\circ} \mathrm{C}\right)$, tolerance on different $\mathrm{pH}$ conditions and survival under different temperatures. Moreover, in this study we have modelled the growth rate of P. agglomerans according to temperature and $\mathrm{a}_{\mathrm{w}}$, two major factors affecting bacteria growth.

$P$. agglomerans growth was higher than on unmodified medium when polyethylene glycol was used to modify $\mathrm{a}_{\mathrm{w}}$. Teixido et al. (2006) found that $P$ agglomerans was less tolerant of low $\mathrm{a}_{\mathrm{w}}$ in the presence of polyethylene glycol on medium, this difference of results may be due to the strain nature and isolation environment. In the presence of the glucose the growth was very limited under the three temperatures. Also the results show that, on basic medium supplemented or not with various solutes used to after the water activity of the medium, $P$. agglomerans grows best at temperature of $25^{\circ} \mathrm{C}$ and at an $\mathrm{a}_{\mathrm{w}}$ ranging from 0.96 to 9.98 . At low temperature $\left(7^{\circ} \mathrm{C}\right), P$. agglomerans can grow at a low $\mathrm{a}_{\mathrm{w}}(0.95)$, depending on the solute used to reach this $\mathrm{a}_{\mathrm{w}}$. Similar studies have been carried out reported that other $P$. agglomerans strain and fugal species can grow at low $\mathrm{a}_{\mathrm{w}}$ under $25^{\circ} \mathrm{C}$ (Teixido et al., 2006 ; Lahlali et al., 2005). The choice of solute used to modify the water activity of a medium has a significant impact on the growth rate of P.agglomerans (Teixido et al., 2006).

Our study likewise show that polyethylene glycol, glycerol and $\mathrm{NaCl}$ have a lesser effect on the growth rate of $P$. agglomerans than glucose, and it was higher on the presence of polyethylene glycol than unmodified medium.

Most predictive models have been developed for pathogenic bacteria. The main problem was that the difficulty of acquiring sufficient reproducible data, suitable for modelling (Buchanan, 1993; Gibson and Hocking, 1997). In the presence study we have modelled the combined effects of temperature and $\mathrm{a}_{\mathrm{w}}$ on the $P$ agglomerans growth rate. The data obtained with polyethylene glycol, glycerol and $\mathrm{NaCl}$ were modelled by means of linear model.

The model provide better understanding of the development of antagonist $P$. agglomerans. It give a better idea of antagonist respecting the temperature and $\mathrm{a}_{\mathrm{w}}$. Concerning the $\mathrm{pH}$ conditions, we improve the good adaptation of $P$. agglomerans under a large range of $\mathrm{pH}$ conditions. Moreover, the growth of $P$. agglomerans 2066-7 strain was very effective inside onion bulb wounds at $7^{\circ} \mathrm{C}$ and $25^{\circ} \mathrm{C}$. A similar colonization of $P$. agglomerans strains was reported on apple and pear wounds under cold temperature at different atmospheric conditions (Bennik et al., 1998; Nunes et al., 2001).

This indicates an excellent adaptation of strain 2066-7 to cold storage and $25^{\circ} \mathrm{C}$ temperature, which is an important feature for biological control agents of onion diseases. The antagonist could survive in the microenvironment of the wound and prevent disease.

Acknowledgements: The authors are grateful to the regional center of the National Institute for Agricultural Research Meknes (INRA), for their financial support and to Dr. Abdelghani Nabloussi, unit coordinator of the de Recherche and Mr. Lahcen Hssaini technician in INRA for their help in statistical analysis.

\section{REFERENCES}

BENNIK, M.H.J., VORSTMAN, W., SMID, E.J., GORRIS, L.G.M. 1998. The influence of oxygen and carbon dioxide on the growth of prevalent Enterobacteriaceae and Pseudomonas species isolated from fresh and controlledatmosphere-stored vegetables. Food Microbiology, 15, 459-469. http://dx.doi.org/10.1006/fmic.1998.0187.

BUCHANAN, L.R. 1993. Predictive food microbiology. Trends in Food Science \& Technology, 4, 6-11. http://dx.doi.org/10.1016/S0924-2244(05)80004-4 CAÑAMAS T.P., VIÑAS I., ABADIAS M., USALL J., TORRES R., TEIXIDO N. 2009. Acid tolerance response induced in the biocontrol agent Pantoed agglomerans CPA-2 and effect on its survival ability in acidic environments.
MicrobioLogicaL
Research,
164 ,
$438-450$.

http://dx.doi.org/10.1016/j.micres.2007.02.007.

COSTA E, USALL J, TEIXIDÓ N, DELGADO J, VIÑAS I 2002, Water activity, temperature, and $\mathrm{pH}$ effects on growth of the biocontrol agent Pantoea agglomerans CPA-2 Can. J. Microbiol, 48, 1082-1088. http://dx.doi.org/10.1139/w03-001

DROBY, S., CHALUTZ, E. 1992. Biological control of postharvest diseases: a promising alternative to the use of synthetic fungicides. Phytoparasitica Suppl, 20, 149-153. http://dx.doi.org/10.1007/BF02980427.

GIBSON, A.M., HOCKING, A.D., 1997. Advances in the predictive modelling of fungal growth in food. Trends in Food Science \&Technology, 8, 353- 358 http://dx.doi:10.1016/S0924-2244(97)01065-0

HALLSWORTH, J.E., MAGAN, N. 1994a. Effects of KCl concentration on accumulation of acyclic sugar alcohols and trehalose in conidia of three entomopathogenic fungi. Lett Appl Microbiol, 18, 8-11. http://dx.doi.org/10.1111/j.1472-765X.1994.tb00785.x.

HALLSWORTH, J.E., MAGAN, N. 1994b. Effect of carbohydrate type and concentration on polyhydroxy alcohol and trehalose content of conidia of three entomopathogenic fungi. Microbiology, 140, 2705-2713. http://dx.doi.org/10.1099/00221287-140-10-2705.

LAHLALI, R., SERRHINIB, M.N., JIJAKLI, M.H. 2005. Studying and modelling the combined effect of temperature and water activity on the growth rate of P. expansum. International Journal of Food Microbiology. 103, 315322. http://dx.doi.org/10.1016/j.ijfoodmicro.2005.02.002.

MAGAN, N., LACEY, J., 1988. Ecological determinants of mould growth in stored grain. International Journal of Food Microbiology, 7, 245-256. http://dx.doi.org/10.1016/0168-1605(88)90043-8 .

MATHIOUTHI, M. 2001. Water content, water activity, water structure and the stability of foodstuffs. Food Control, 12, 409-417. http://dx.doi.org/10.1016/S0956-7135(01)00032-9.

NUNES, C., USALL, J., TEIXIDO, N., VINAS, I. 2001. Biological control of postharvest pear diseases using a bacterium Pantoea agglomerans (CPA-2). Int $J$ Food Microbiol, 70, 53-61. http://dx.doi.org/10.1016/S0168-1605(01)00523-2.

PLAZA, P., USALL, J., TEIXIDO, N., VINAS, I. 2003. Effect of water activity and temperature on germination and growth of Penicillium digitatum, P. italicum and Geotrichum candidum. Journal of Applied Microbiology, 94, 549- 554 http://dx.doi.org/10.1046/j.1365-2672.2003.01909.x.

RHODES, D J. 1993. Formulation of biological control agents. In Exploitation of Microorganisms ed. Jones, D.G. pp. 411-439. London: Chapman \& Hall http://dx.doi.org/10.1007/978-94-011-1532-2 16

TEIXIDO, N., CANAMAS, T.P., ABADIAS, M., USALL, J., SOLSONA, C., CASALS, C., VINÂS, I.2006. Improving low water activity and desiccation tolerance of the biocontrol agent Pantoea agglomerans CPA-2 by osmotic treatments. Journal of Applied Microbiology, ISSN, 1364-5072. http://dx.doi.org/10.1111/j.1365-2672.2006.02948.x

VINAS, I., USALL, J., TEIXIDO' N., SANCHIS, V. 1998. Biological control of major postharvest pathogens on apple with Candida sake. Int J Food Microbiol, 40, 9-16. http://dx.doi.org/10.1016/S0168-1605(98)00009-9. 